\title{
Monitoring of mining areas in relation to various reference networks
}

\author{
Andrzej Uznański ${ }^{1, *}$ \\ ${ }^{1}$ AGH University of Science and Technology, Faculty of Mining Surveying and Environmental \\ Engineering, Krakow, Poland
}

\begin{abstract}
Static satellite surveying techniques are commonly used for the geodetic monitoring of mining areas, especially to determine horizontal coordinates of points. Satellite surveys are currently being connected to permanently established reference stations. In many countries, two or more reference networks work independently. In Poland, there are four nationwide networks of reference stations and one regional network. All commercial networks must be tied to the national network ASG-EUPOS. This research paper has analysed the influence of tying the points used for mining area monitoring purposes to various reference networks on their adjusted coordinates. The author has attempted to process the results of these satellite surveys at the engineering level, most frequently encountered in the field of surveying. The computation has been carried out using commercial software. Static observations from four reference networks operating in Poland have been used to compute the coordinates of the test points: ASG-EUPOS, NadowskiNET, TPINetPRO and VRSNet.pl. Leica Geosystems Polska has not provided access to its static satellite observations for testing purposes.
\end{abstract}

Keywords: monitoring, mining areas, static satellite surveys, CORS, ASG-EUPOS, NadowskiNET, TPINet ${ }^{\text {PRO }}$, VRSNet.pl

\section{Introduction}

The operation of a mining plant is largely based on the results of geodetic surveys, which are utilised to prepare the surveying-geological documentation for the mining area. The entrepreneur is obliged to have their surveying-geological documentation updated and supplemented as the works progress. The documentation includes cartographic documents presenting the current geological and mining situation of the mining plant, as well as the condition of the surface within the mining area, i.e. the space anticipated to be affected by the harmful effects of mining exploitation [1]. In order to prepare, update and supplement this documentation, land surveys and various geological works are carried out, including measurement, computation and cartographic activities. Detailed requirements for the

\footnotetext{
* Corresponding author: auznan@agh.edu.pl
} 
performance of land surveys are included in Appendix No. 1 to [2]. In its content, the most important are the provisions related to the geodetic control network, together with the reference to the Regulation on the national system of spatial references [3]. As regards the implementation of the surveys associated with the establishment and maintenance of geodetic control networks, the Appendix refers to the Regulation issued by the Head Office of Geodesy and Cartography on geodetic, gravimetric and magnetic control networks [4]. On the other hand, the Appendix of Regulation of control networks shows the use of satellite surveys in determining the coordinates of geodetic control points. Currently, the basic legal act regulating the performance of the plane and vertical topographic surveys is the Regulation of the Minister of Interior and Administration of November 9, 2011 on technical standards of performance of plane and vertical land surveys as well as processing and submitting the results of these surveys to the national geodetic and cartographic resource [5].

Static satellite surveys are currently the basis for determining the coordinates of the geodetic control points, as they allow to obtain high and homogeneous accuracy of the coordinates of the network points. This is a great advantage for extensive survey areas, with no aiming direction between the neighbouring points, and for linear objects, for which an alternative is a traverse with a great propagation of errors. Monitoring surveys capture the current coordinates of the control points. The main issue is to determine whether the differences between the current and the previous coordinates result from deformations and displacements caused by mining exploitation or whether they are within the measurement accuracy predicted for a specific surveying technique. In the case of satellite surveys, the issue is not trivial. Despite several decades of using satellite surveys in geodesy, this thesis has been confirmed by the analysis of the results of static satellite surveys performed in 2013, published in [6].

Satellite measurements have been used in monitoring of the engineering structures and terrain for many years, both static measurements presented in the work from 1989 [7] and RTK GPS from 1997 [8]. The literature of the subject is therefore very extensive. The general introduction to monitoring issues, also using satellite measurements, is [9]. The problem of using satellite measurements in monitoring focuses on [10]. There are many monitoring systems in the world [11].

The objective of this research paper has been to present a comparative analysis of the coordinates of the points computed from static satellite observations tied to various reference networks operating in Poland. The analyses and conclusions have been presented based on the satellite observations recorded in five surveys carried out with four GNSS receivers on five points of the test control network located in the area which is free from the environmental impact of mining.

\section{Reference networks in Poland}

In Poland, there are currently five CORS networks providing satellite reference data, both for the post-processing and for the real-time streams. The highest class is awarded to the ASG-EUPOS national network points, which was the first nationwide CORS network in Poland made available to the users in mid-2008. It considerably popularised the use of satellite surveys among land surveyors, which was evidenced by the establishment of another four commercial networks by the distributors of surveying instruments in Poland. These are the following companies, listed in alphabetical order: Leica Geosystems SmartNet as well as the previously established regional network, covering southern Poland - NadowskiNET; Topcon - TPINet ${ }^{\mathrm{PRO}}$; Trimble - VRSNet.pl. All CORS networks share the data for commercial purposes for a fee. This study has used the data from all reference 
networks available free of charge and in full extent, with the exception of the SmartNet, as its owner has not provided access to the static satellite observations for testing purposes.

An important feature of a reference network is the number and location of its reference stations. Figure 1 illustrates the location of the reference stations in the vicinity of the measurement site as well as the vectors computed in the post-processing, identifying the three stations of a given network which the test points have been tied to. The selection of the reference stations to tie the points has been made according to the minimum distance criterion.

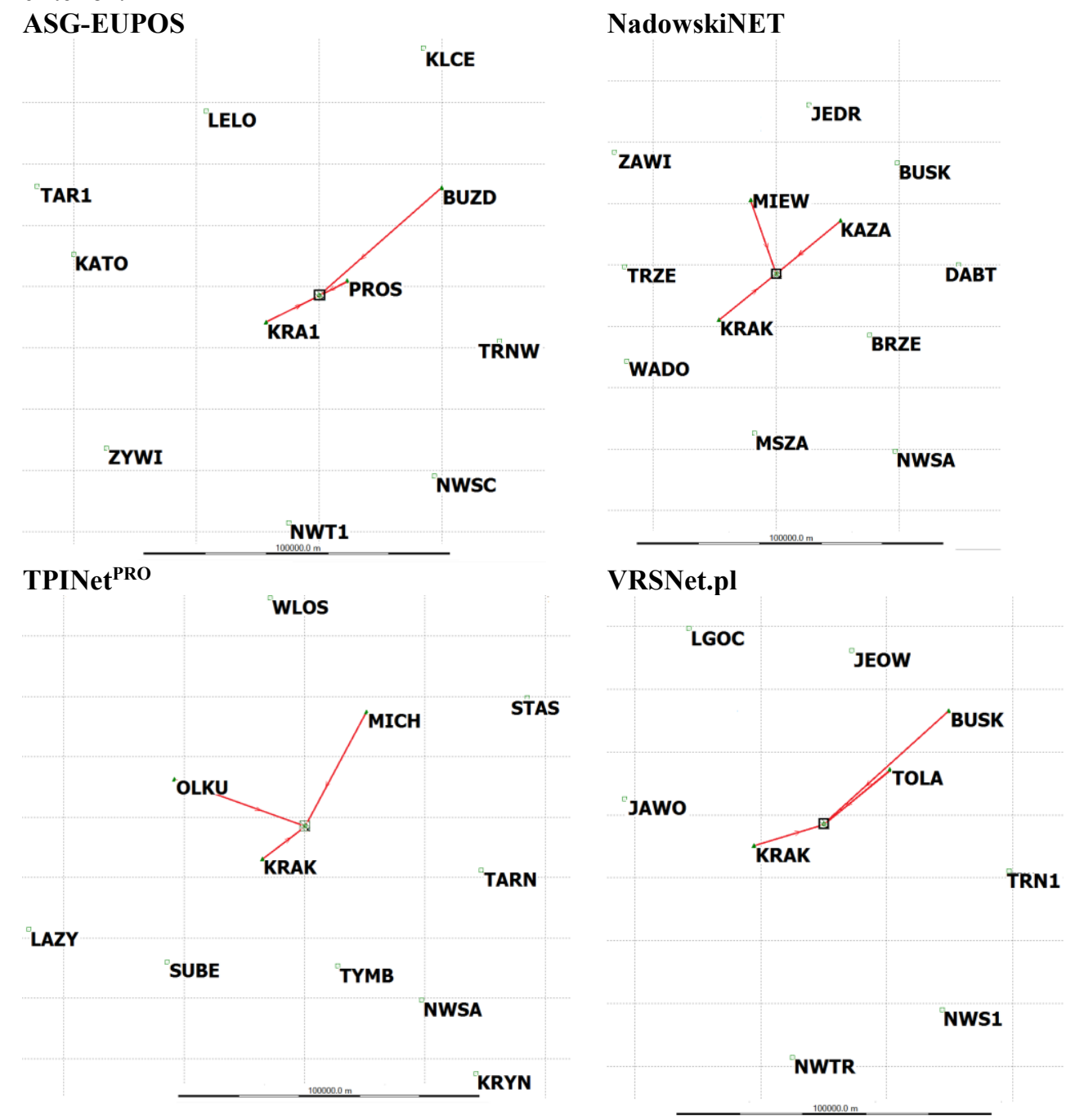

Fig. 1. Location of reference stations of various networks together with reference vectors.

Table 1 contains a list of 10 reference stations for the CORS network, with reference to which the computation has been made. These are the reference stations which are the nearest to the measurement site. The table also demonstrates the distance of the measurement site from these stations. The data reveals that the regional network NadowskiNET, with a total distance of approximately $440 \mathrm{~km}$, has the densest network of reference stations for the measurement site. The density of the reference stations of the other networks is similar and oscillates around $600 \mathrm{~km}$. 
Another important feature of reference networks is the type and method of data sharing. Both ASG-EUPOS and VRSNet.pl use the same Trimble software, and therefore the diversity is smaller in this respect. However, SmartNet and NadowskiNET use Leica Geosystems software, and TPINet ${ }^{\mathrm{PRO}}$ uses Topcon software.

Table 1. Distances of CORS reference stations from measurement site.

\begin{tabular}{|c|c|c|c|c|c|c|c|c|}
\hline & \multicolumn{2}{|c|}{ ASG-EUPOS } & \multicolumn{2}{|c|}{ NadowskiNET } & \multicolumn{2}{|c|}{ TPI NET $^{\text {Pro }}$} & \multicolumn{2}{|c|}{ VRSNet.pl } \\
\hline Lp. & Id & {$[\mathrm{km}]$} & Id & {$[\mathrm{km}]$} & Id & {$[\mathrm{km}]$} & Id & {$[\mathrm{km}]$} \\
\hline 1 & PROS & 10.4 & KRAK & 23.9 & KRAK & 17.8 & KRAK & 23.1 \\
\hline 2 & KRA1 & 19.4 & MIEW & 25.5 & $\mathrm{MICH}$ & 43.0 & TOLA & 27.2 \\
\hline 3 & BUZD & 53.3 & KAZA & 27.2 & OLKU & 46.1 & BUSK & 53.6 \\
\hline 4 & TRNW & 60.7 & BRZE & 36.5 & TYMB & 47.4 & JEOW & 55.9 \\
\hline 5 & NWSC & 70.0 & TRZE & 49.5 & TARN & 60.3 & TRNW & 60.7 \\
\hline 6 & LELO & 70.7 & MSZA & 52.4 & SUBE & 64.1 & JAWO & 63.7 \\
\hline 7 & NWTG & 74.5 & BUSK & 53.6 & NWSA & 69.5 & NWSC & 70.0 \\
\hline 8 & KATO & 81.2 & JEDR & 56.0 & WLOS & 76.5 & NWTR & 74.9 \\
\hline 9 & ZYWI & 85.6 & WADO & 56.5 & KIEL & 85.2 & LGOC & 75.6 \\
\hline 10 & KLCE & 87.7 & DABT & 59.5 & STAS & 85.3 & WLOS & 78.7 \\
\hline \multicolumn{2}{|c|}{ Total [km]: } & 613.4 & \multicolumn{2}{|c|}{440.5} & \multicolumn{2}{|c|}{595.3} & \multicolumn{2}{|c|}{583.3} \\
\hline
\end{tabular}

The software of ASG-EUPOS and VRSNet.pl generates data upon an individual request of the user. Similar is the case with the SmartNet network. On the other hand, in NadowskiNet and TPINet ${ }^{\mathrm{PRO}}$, the data is automatically generated, archived, and the users select the data they are interested in from the ready files, according to their own needs. In practice, the period of availability of archival satellite observations is important. In the case of the ASG-EUPOS network and VRSNet.pl, the observations can be ordered up to 12 months beforehand from the date of placing an order. The observations can be ordered from both the real and virtual stations, having entered their coordinates in the WGS-84 system. The observations from the virtual stations can not be ordered from other CORS networks. The satellite data is made available in the Rinex format, as it is a standard for recording satellite observations in a format which is independent of the receiver. The selection is as follows: Rinex 2.10, 2.11, 3.00 (de facto 3.02) DAT, TGD, T01, T02.

As for NadowskiNET, the observations are automatically generated by the software for each network reference station in a one-second interval, and then they are stored on the server for two weeks only. After that, they are deleted. The files ready to be downloaded contain satellite observations from the subsequent four hours of a given day in the Rinex 2.11 format.

As far as TPI company is concerned, in mid-2017, there was a change in their data archiving procedure, which resulted in the lack of data for surveys conducted in July. The data that had previously been available since 2015, has only now become available for the last 31 days in the catalogues marked with a date. The daily catalogue includes subcatalogues with the observations in $1 \mathrm{~s}, 5 \mathrm{~s}, 30 \mathrm{~s}$ intervals and the catalogues with the name of the station. In the catalogues denoted with the name of the reference station, there are 24 one-hour files with one-second observations in the Rinex 2.11 format. The remaining catalogues contain compressed files (zip files) with daily observations in the Rinex 2.11 format, saved in the interval compliant with the catalogue name (1, 5 or $30 \mathrm{~s})$. In the [nav] catalogue, ephemerides for the GPS and GLONASS systems are made available.

The figure below illustrates the details of the available reference data of the NWT1 station of the ASG-EUPOS network. The data recorded for $12 \mathrm{~h}$ and 31 ' can not be used to 
tie control points due to the very short availability periods. For date of 3 July, no observations for the PROS station have been obtained from the ASG-EUPOS network.

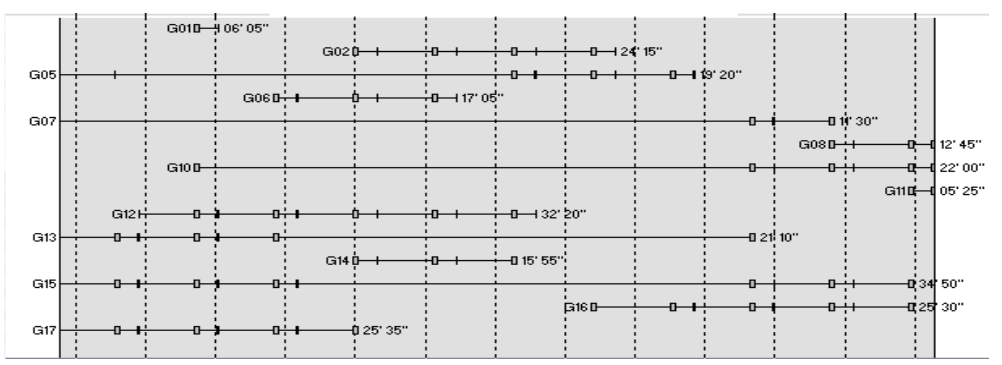

Fig. 2. Satellite window of NWT1 station of ASG-EUPOS network.

Unidentified problems with the data from the NWSA station of the TPINet ${ }^{\text {PRO }}$ network have also occurred for two of the five measurement days (Fig. 3a). The data downloaded from the TPINet ${ }^{\mathrm{PRO}}$ network could not be used practically. This station has been claimed to have occured in the NadowskiNET network as well. This is the same station because its coordinates are identical in both networks. Interestingly, the data from this station provided by NadowskiNet (Fig. 3b) are complete for those days. For example, for the analogous periods of time (time windows illustrated in Figure $3 \mathrm{a}$ and $3 \mathrm{~b}$ are not equivalent), for the G02 satellite from NadowskiNET, almost $5 \mathrm{~h}$ of the data was made available in one time interval. From the TPINet ${ }^{\text {PRO }}$ network, only $2 \mathrm{~h} 13^{\prime}$ of the data for this satellite have been made available in 18 time intervals.

The above-mentioned problems and random failures of reference stations may force the need to change the CORS network used to tie point surveys in the object and area monitoring.
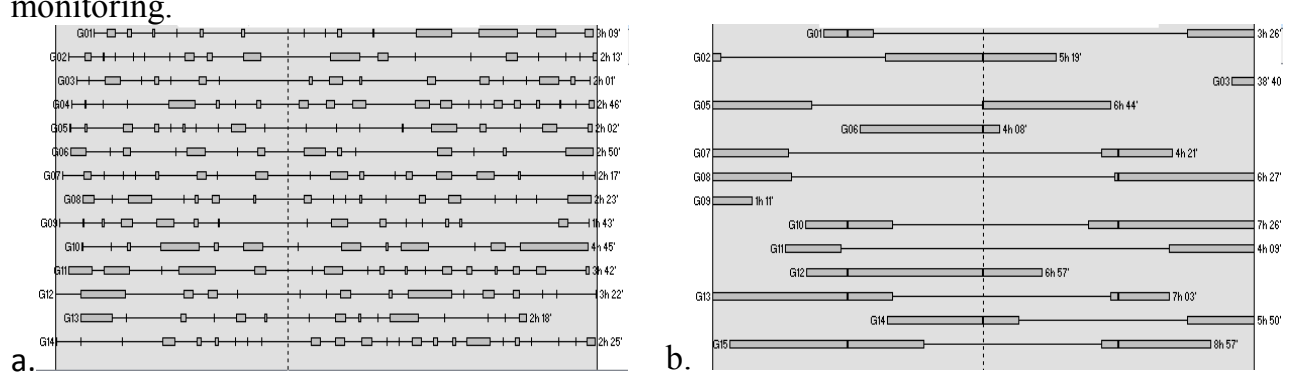

Fig. 3. Data from NWSA reference station of: a. TPINet ${ }^{\mathrm{PRO}}$ network, b. of NadowskiNET.

\section{Geodetic control network}

In this research paper, the issue of control networks will be presented in the context of classifying reference stations of the CORS network as geodetic control points. The control point is defined by the Regulation of the Minister of Administration and Digitization of 14 February 2012 on geodetic, gravimetric and magnetic control networks [4]. Control networks are classified according to the criterion of accuracy and the method of their tying, as:

- zero-order (fundamental) geodetic control, class 1 ,

- first-order (basic) geodetic control, class 2 ,

- second-order (detailed) geodetic control, class 3. 
The basic criterion for qualifying a control point to a specific class is the accuracy of determining the values which are appropriate for a given type of the control network. Most frequently, these are the coordinates of the control point. The Regulation [4] defines the class of the geodetic control network as a feature that determines "its importance in surveying and cartographic work, the order in which control points are included in the adjustment process, and the accuracy of the determination after the observations have been adjusted". The accuracy of the geodetic control point is determined by the value of the mean error of the determined value. Due to the specificity of the surveying techniques and systems as well as the reference systems, control networks are also divided into horizontal and vertical ones.

The zero-order horizontal network in Poland is made up of the reference stations in the ASG-EUPOS network, which belong to the EPN (European Permanent Network). The mean error of the horizontal position of the point of this control should not exceed $0.01 \mathrm{~m}$ and of the vertical position $-0.02 \mathrm{~m}$. Other reference stations of ASG-EUPOS are classified as the first-order (basic) geodetic control.

Having met the relevant requirements and having been accepted into the National Geodetic and Cartographic Documentation Resource, the reference stations of the commercial networks are classified as the second-order (detailed) geodetic control, as their coordinates have been determined by tying to the reference stations of the ASG-EUPOS network.

Currently, the reference stations of various networks are the most commonly used geodetic control points for tying all surveys. Static observations are made available to the users upon their request and for a fee. It should be emphasised, that a reference station can be treated as a geodetic control point only after it has been accepted to the National Geodetic and Cartographic Documentation Resource.

\section{Satellite surveys and their processing}

The location of the test points has been selected with regard to the analyses of the results obtained by satellite surveys. Therefore, in order to preserve the repeatability of the measurement results in the analyses, these points have been located in an area which has not been affected by mining, and the horizons around them have not been obscured or covered. The distances between the points ranged from a dozen to several dozen meters.

The satellite observations recorded in five surveys performed with four GNSS receivers on five points of the test control network have been the subject of the post-processing. The observations in three twelve-hour static sessions, and a fourth shorter one, have been recorded on four points. The fifth point has been laid down in July. Table 2 summaries the information on the dates and times of the satellite static surveys performed on individual points. Two surveys were conducted in June, and another three after about a month.

Table 2. Length of static sessions on test points [hh:mm].

\begin{tabular}{|c|c|c|c|c|c|}
\hline Point/date dd.mm & 06.06 & 10.06 & 03.07 & 04.07 & 07.07 \\
\hline 01 & $12: 46$ & $12: 26$ & $8: 09$ & $12: 01$ & --- \\
\hline 02 & $12: 34$ & $12: 19$ & --- & $1: 46$ & $12: 08$ \\
\hline 03 & $12: 25$ & $7: 42$ & $7: 12$ & $11: 58$ & --- \\
\hline 04 & $12: 14$ & $12: 15$ & --- & --- & $12: 02$ \\
\hline 05 & --- & --- & $6: 44$ & $12: 06$ & $12: 00$ \\
\hline
\end{tabular}


For the ASG-EUPOS network, the surveys have been referred to the PROS, KRA1, and BUZD stations (Fig. 1). For $3^{\text {rd }}$ July, no observations for the PROS station have been obtained, so the observations of the TRNW station, as the nearest one to the measured points, have been used. As far as TPINet ${ }^{\mathrm{PRO}}$ is concerned, due to an unexpected change in data archiving rules, the data for the July surveys could not be downloaded.

The computation standard has been adopted at the engineering level, most common in surveying. For this reason, the computations have been carried out in commercial software (Leica Geo Office v. 8.4), with minimal interference in the default settings of postprocessing and adjustment parameters. Post-processing has been performed with the following parameters:

$-10^{0}$ minimum horizontal height of satellites,

- broadcast ephemerides,

- NAVSTAR GPS, GLONASS satellite systems,

- 5s observation epoch,

- troposphere model - default (H.Hopfield),

- ionosphere model selected by the software in an automatic and optimal manner.

The adjustment of satellite vectors has been performed on the WGS-84 ellipsoid assuming the correctness of the reference points, according to [4]. The adjusted coordinates, transformed into the PL-2000 national system, have formed the basis for the comparative analyses.

The provisions of the Regulation on Standards [5] have been taken account of in the measurements and computations. As regards satellite surveying of geodetic control networks, this Regulation stipulates the following as necessary:

- establishing horizontal control points tied to the horizontal geodetic control network in the form of a network of points determined by the precise positioning method using GNSS,

- providing a multi-point reference to the points of the horizontal geodetic network,

- performing at least two surveys of each measured vector,

- performing supernumerary observations.

\section{Analysis of results}

Reference stations of the CORS ASG-EUPOS national network are treated in accordance with the regulations as points of the highest-order control networks, i.e. the zero-order and the first-order ones. The reference stations of the commercial networks are classified as second-order points. Therefore, in the strategy of the analysis, it would be reasonable to assume the coordinates of the test points, computed in relation to the ASGEUPOS network, as reference coordinates for the coordinates computed in relation to other commercial networks. Some doubts, however, have arisen as to the validity of such an assumption. The reason has been the analysis of the coordinate differences of the test points computed in reference to the reference stations of a given reference network on the subsequent days of the measurements. Table 3 demonstrates the computed values of ranges $\Delta$ for the values of the coordinates (for example $\mathrm{D} y=\mathrm{y}_{\max }-\mathrm{y}_{\min }$ ) and of the standard deviations. The individual networks have been denoted with the first letters of their names: A - ASG-EUPOS, N - NadowskiNET, T - TPINet ${ }^{\text {PRO }, ~ V ~-~ V R S N e t . p l . ~ T h e ~ p o i n t ~} 05$ was monumented in July, and it was not possible to download the reference data of the TPINet $^{\text {PRO }}$ network from this month due to a change in data archiving rules.

The computed values of the statistics demonstrate that the greatest differentiation of the computed coordinates of the points has occurred when they have been tied to the ASGEUPOS network. In the case of the ASG-EUPOS network, the range of results is significantly larger, often twice as much as for other networks, and sometimes even larger. 
The values of standard deviations are not as discrepant as the values of the data ranges. Nevertheless, in most cases, standard deviations assume the largest values again when being tied to the ASG-EUPOS network and, most importantly, they differ from the values of the ranges, in contrast to the results obtained for other networks. This may indicate individual values that are more different than others. In the case of a small sample size, it has been necessary to analyse the June and July surveys separately. The analysis concerns the results captured from a minimum of two or three twelve-hour sessions for each of the test points. With such long sessions, differences in results at the level of $1 \mathrm{~cm}$, and even exceeding this value and reaching $1.5 \mathrm{~cm}$, should be considered unsatisfactory for this surveying technique. For the ASG-EUPOS network, the analysis was performed separately for June and July surveys. The values of the ranges of the coordinates of the points tied to the ASG-EUPOS network have significantly decreased, showing a discrepancy of the results in individual months. When tied to other networks, this effect has not occurred. This phenomenon is particularly dangerous in monitoring, since the results can be interpreted as displacements or deformations of the area where the control points have been measured. Also, significantly larger differences for the " $x$ " coordinates than for the " $y$ " coordinates are characteristic.

Table 3. Values of differences in coordinates of points computed with reference to the network $[\mathrm{m}], \Delta$ - range, s.d - standard deviation.

\begin{tabular}{|c|c|c|c|c|c|c|c|c|c|c|}
\hline Point & \multicolumn{2}{|c|}{01} & \multicolumn{2}{c|}{02} & \multicolumn{2}{c|}{03} & \multicolumn{2}{c|}{04} & \multicolumn{2}{c|}{05} \\
\hline CORS & $\mathrm{y}$ & $\mathrm{x}$ & $\mathrm{y}$ & $\mathrm{x}$ & $\mathrm{y}$ & $\mathrm{x}$ & $\mathrm{y}$ & $\mathrm{x}$ & $\mathrm{y}$ & $\mathrm{x}$ \\
\hline $\mathbf{A} \boldsymbol{\Delta}$ & $\mathbf{0 . 0 0 8}$ & $\mathbf{0 . 0 1 4}$ & $\mathbf{0 . 0 0 8}$ & $\mathbf{0 . 0 1 2}$ & $\mathbf{0 . 0 1 0}$ & $\mathbf{0 . 0 1 5}$ & $\mathbf{0 . 0 0 6}$ & $\mathbf{0 . 0 1 2}$ & $\mathbf{0 . 0 0 4}$ & $\mathbf{0 . 0 0 3}$ \\
\hline A s.d. & 0.003 & 0.006 & 0.004 & 0.006 & 0.004 & 0.007 & 0.003 & 0.006 & 0.002 & 0.002 \\
\hline A $\boldsymbol{\Delta}$ June & $\mathbf{0 . 0 0 5}$ & $\mathbf{0 . 0 0 6}$ & $\mathbf{0 . 0 0 6}$ & $\mathbf{0 . 0 0 5}$ & $\mathbf{0 . 0 0 6}$ & $\mathbf{0 . 0 0 6}$ & $\mathbf{0 . 0 0 4}$ & $\mathbf{0 . 0 0 3}$ & --- & --- \\
\hline A $\boldsymbol{\Delta}$ July & $\mathbf{0 . 0 0 4}$ & $\mathbf{0 . 0 0 1}$ & --- & --- & $\mathbf{0 . 0 0 4}$ & $\mathbf{0 . 0 0 1}$ & --- & --- & $\mathbf{0 . 0 0 4}$ & $\mathbf{0 . 0 0 3}$ \\
\hline N $\boldsymbol{\Delta}$ & 0.003 & 0.007 & 0.002 & 0.006 & 0.002 & 0.009 & 0.003 & 0.008 & 0.000 & 0.004 \\
\hline N s.d. & 0.002 & 0.004 & 0.001 & 0.003 & 0.001 & 0.005 & 0.002 & 0.004 & 0.000 & 0.003 \\
\hline T D June & 0.005 & 0.001 & 0.007 & 0.000 & 0.007 & 0.000 & 0.005 & 0.003 & --- & --- \\
\hline T s.d. & 0.004 & 0.000 & 0.005 & 0.000 & 0.005 & 0.000 & 0.003 & 0.002 & --- & --- \\
\hline V D & 0.004 & 0.007 & 0.003 & 0.011 & 0.005 & 0.008 & 0.003 & 0.010 & 0.003 & 0.003 \\
\hline V s.d. & 0.002 & 0.003 & 0.002 & 0.005 & 0.002 & 0.004 & 0.001 & 0.005 & 0.001 & 0.002 \\
\hline
\end{tabular}

An analogous vertical analysis has demonstrated that for the majority of the networks the ranges have been at the level of a decimetre, reaching even $16 \mathrm{~cm}$ (Table 4), except for the TPINet ${ }^{\mathrm{PRO}}$, for which they have remained at the level of $5 \mathrm{~mm}$, but only due to the lack of computations for the July surveys. The analysed results, grouped according to the respective months, have been denoted as in table 3 . No result contained in the table means that there is no available data or only one survey in a specific month. In the case of a single survey performed in a given month, the range of non-grouped surveys is significantly different from the value computed for one of the months. The results contained in the tables 3 and 4 have resulted in resigning from the analyses using averaged values of the point coordinates since it would be impossible to formulate any meaningful conclusions with the differences in horizontal coordinates at the level of $15 \mathrm{~mm}$, occurring as a result of tying the points to the ASG-EUPOS network. It has been necessary to analyse the results obtained for each measurement day separately. 
Table 4. Analysis of differences in heights of points tied to different networks [m].

\begin{tabular}{|c|c|c|c|c|c|c|c|c|c|c|}
\hline Point & $\begin{array}{c}\mathrm{A} \\
\text { all }\end{array}$ & $\begin{array}{c}\mathrm{A} \\
\text { June }\end{array}$ & $\begin{array}{c}\mathrm{A} \\
\text { July }\end{array}$ & $\begin{array}{c}\mathrm{N} \\
\text { all }\end{array}$ & $\begin{array}{c}\mathrm{N} \\
\text { June }\end{array}$ & $\begin{array}{c}\mathrm{N} \\
\text { July }\end{array}$ & $\begin{array}{c}\mathrm{T} \\
\text { June }\end{array}$ & $\begin{array}{c}\mathrm{V} \\
\text { all }\end{array}$ & $\begin{array}{c}\mathrm{V} \\
\text { June }\end{array}$ & $\begin{array}{c}\mathrm{V} \\
\text { July }\end{array}$ \\
\hline 01 & 0.101 & 0.018 & 0.003 & 0.105 & 0.001 & --- & 0.005 & 0.083 & 0.013 & 0.001 \\
\hline 02 & 0.140 & 0.019 & --- & 0.128 & 0.000 & --- & 0.004 & 0.160 & 0.014 & --- \\
\hline 03 & 0.134 & 0.019 & 0.009 & 0.104 & 0.000 & --- & 0.004 & 0.144 & 0.014 & --- \\
\hline 04 & 0.037 & 0.023 & --- & 0.024 & 0.004 & --- & 0.000 & 0.058 & 0.018 & --- \\
\hline 05 & 0.013 & --- & 0.013 & 0.022 & --- & 0.022 & --- & 0.019 & --- & 0.019 \\
\hline
\end{tabular}

The results summarised in the table below demonstrate the occurrence of differences in the results which are clearly systematic for the type of coordinate and the measurement day. A positive aspect of this observation is a conclusion on the possibility of tying points to various reference networks. Practically, this involves only the determination of the translation vector, without any strain to the transformed results. Significantly greater differences in heights with respect to the ASG-EUPOS network have occurred for the NadowskiNET. Interestingly, these results have been the most consistent with the results of the RTN surveys performed together with the static surveys. Based on the obtained results, it can be concluded that if the surveyor changes the CORS network used to tie surveys in monitoring, it will not be as problematic as carrying out the surveys at a different date.

Table 5. Differences in coordinates of points tied to ASG-EUPOS network and commercial networks $[\mathrm{m}]$.

\begin{tabular}{|c|c|c|c|c|c|c|c|c|c|c|}
\hline \multirow[t]{2}{*}{ Date } & \multirow{2}{*}{\begin{tabular}{|l} 
CORS \\
Point \\
\end{tabular}} & \multicolumn{3}{|c|}{$\begin{array}{l}\text { ASG-EUPOS- } \\
\text { NadowskiNet }\end{array}$} & \multicolumn{3}{|c|}{$\begin{array}{c}\text { ASG-EUPOS - } \\
\text { TPINet }^{\mathrm{PRO}}\end{array}$} & \multicolumn{3}{|c|}{$\begin{array}{c}\text { ASG-EUPOS - } \\
\text { VRSNet.pl }\end{array}$} \\
\hline & & $\mathrm{y}$ & $\mathrm{x}$ & $\mathrm{h}$ & $\mathrm{y}$ & $\mathrm{x}$ & $\mathrm{h}$ & $\mathrm{y}$ & $\mathrm{x}$ & $\mathrm{h}$ \\
\hline \multirow{4}{*}{6.06} & 01 & 0.000 & -0.009 & -0.066 & -0.002 & -0.018 & 0.007 & -0.001 & -0.007 & 0.040 \\
\hline & 02 & -0.001 & -0.009 & -0.065 & -0.002 & -0.018 & 0.007 & -0.001 & -0.007 & 0.040 \\
\hline & 03 & -0.001 & -0.009 & -0.065 & -0.002 & -0.018 & 0.007 & -0.001 & -0.007 & 0.040 \\
\hline & 04 & 0.000 & -0.009 & -0.065 & -0.002 & -0.018 & 0.007 & -0.001 & -0.007 & 0.040 \\
\hline \multirow{4}{*}{10.06} & 01 & 0.007 & -0.003 & -0.084 & -0.003 & -0.013 & -0.016 & 0.004 & -0.007 & 0.036 \\
\hline & 02 & 0.007 & -0.003 & -0.084 & -0.003 & -0.013 & -0.016 & 0.004 & -0.007 & 0.036 \\
\hline & 03 & 0.007 & -0.003 & -0.083 & -0.003 & -0.013 & -0.016 & 0.004 & -0.007 & 0.036 \\
\hline & 04 & 0.007 & -0.003 & -0.083 & -0.003 & -0.013 & -0.016 & 0.004 & -0.007 & 0.036 \\
\hline \multirow{3}{*}{3.07} & 01 & --- & --- & --- & --- & --- & --- & 0.000 & 0.001 & 0.025 \\
\hline & 03 & --- & --- & --- & -- & --- & --- & 0.000 & 0.000 & 0.025 \\
\hline & 05 & --- & --- & --- & --- & --- & --- & 0.000 & 0.000 & 0.024 \\
\hline \multirow{3}{*}{4.07} & 01 & -0.001 & -0.002 & -0.062 & --- & --- & --- & 0.002 & 0.000 & 0.021 \\
\hline & 03 & -0.001 & -0.002 & -0.063 & --- & --- & --- & 0.002 & 0.000 & 0.021 \\
\hline & 05 & -0.001 & -0.003 & -0.063 & --- & --- & --- & 0.002 & 0.000 & 0.022 \\
\hline \multirow{3}{*}{7.07} & 02 & -0.002 & -0.001 & -0.072 & --- & --- & --- & 0.000 & -0.005 & 0.015 \\
\hline & 04 & -0.002 & -0.001 & -0.071 & --- & --- & --- & 0.000 & -0.005 & 0.014 \\
\hline & 05 & -0.002 & -0.002 & -0.072 & --- & --- & --- & 0.000 & -0.005 & 0.016 \\
\hline
\end{tabular}


The analyses have concluded that the reference to the ASG-EUPOS network has provided the most diversified results. Assuming the results of the computations performed on the first day (when a given point was measured for the first time) to be a reference result for coordinate differentiation for subsequent days, it can be established that out of 17 differences in the horizontal position, 6 have been greater than $1 \mathrm{~cm}$, which accounts for $35 \%$ of the results.

\section{Summary and conclusions}

Satellite surveying techniques have been used in commercial geodetic surveys in Poland since the mid-1990s, that is to say, for almost a quarter of a century. The independent operation of several different reference networks in Poland has prompted the author of this research paper to examine the differences in results that can be captured by referring the same test points to these networks. The reference networks differ in the location of their reference stations, the version of the format of the available data, the various density of reference stations in a given area of the country.

The analysis of the coordinates of the points computed in each network has demonstrated that the largest differences in the values of these coordinates have occurred as as result of tying them to the national network ASG-EUPOS, whose points are classified as the second-order points. The results of tying the points to this network have most significantly been influenced by the almost one-month time interval in the implementation of the two series of static surveys. It should be emphasized at this point that the surveys performed as part of the mining area monitoring procedure have their specificity. A correct interpretation of the results of geodetic surveys as well as a correct identification of the quality of the results of a given surveying technique and of the actual changes caused by mining impacts are of great importance.

There are a lot of articles describing the quality of satellite measurement results, but the analyses of the results of satellite surveys captured from tying to various reference networks of the same surveys are a relatively new field of analyses that has emerged together with the construction of new, commercial reference networks. In [12] the precision of satellite measurements results was estimated at 12 to $16 \mathrm{~mm}$ in the horizontal plane and 18 to 24 $\mathrm{mm}$ in elevation. In [13], test measurements were carried out for vectors from $26 \mathrm{~km}$ to 300 $\mathrm{km}$ for static sessions lasting from $4 \mathrm{~h}$ to $24 \mathrm{~h}$. It was found, among others, that heights are 3.6 times less accurately determined than coordinates in the horizontal plane. The development of hardware and software may call into question the validity of results from 20 years ago. In the article [14] from 2011, the accuracy of satellite measurements was estimated with sessions $6 \mathrm{~h}$ or longer and four or more reference stations, the precision is typically $1-2 \mathrm{~mm}$ in horizontal and about $3-5 \mathrm{~mm}$ in vertical. In [11] from 2018 , the accuracy of determination of coordinates of control points from static measurements was estimated. The calculated average values of coordinate differences are too optimistic in this work. In the case of analysis of coordinate differences determined and assumed as reference coordinates, the average value should be calculated from the absolute values of these differences. The corrected mean values have been $6 \mathrm{~mm}$ for the horizontal coordinates, and $8 \mathrm{~m}$ for the height (twice the value referred to in [11]). The maximum differences between the coordinates of points calculated from the static surveys have reached $14 \mathrm{~mm}$ and 24 $\mathrm{mm}$, respectively. These values coincide with the values calculated in this work with respect to the analyses performed for individual months. In [11], the results of RTN measurements with coordinates calculated from static measurements were compared. Currently, it is the most frequently performed type of quality analysis of satellite measurements results. 
The analysis of the results of the test surveys has demonstrated that changing the reference network only requires the determination of the components of the translation vector and does not result in any friction in the results that could affect the correct interpretation of the actual changes occurring in the mining area. The changes in the values of the components of the translation vector computed for individual measurement days have reached several millimetres for the horizontal coordinates and generally less than 20 $\mathrm{mm}$ for the vertical ones. It can be assumed that these are the values of the estimated accuracy of the determined components of the translation vector in static satellite surveys.

This research paper presents the results of the analyses of the performed test surveys which have focused on the final consequences of changing the reference network used to connect control points in a mining area, without any detailed analyses of various aspects of processing satellite observations. One of these aspects is e.g. a type of software. This study used Leica Geo Office v. 8.4 (LGO) software to process the results of the performed satellite surveys. The quoted publication [6] has described an example in which the quality of satellite survey results has been estimated incorrectly, despite the criteria of the statistical test having been met. This instance has proven that estimating the real quality of satellite results can be difficult. The reliability of surveying results is of great importance. The LGO algorithm uses W. Baarda's reliability theory $[15,16]$.

Most commercial software programmes do not use any computations related to determining the reliability of surveying results. The publication [17] compares the results of automatic and manual post-processing for a point with a very obscured horizon using W. Baarda's reliability theory. In the automatic post-processing, the influence of an undetected gross error on the horizontal coordinates $\varphi$ and $\lambda$ has reached $28 \mathrm{~mm}$ and $16 \mathrm{~mm}$ respectively, and for the height it was as much as $54 \mathrm{~mm}$. In the manual post-processing, these values have been $1 \mathrm{~mm}$ and $2 \mathrm{~mm}$ respectively, and $7 \mathrm{~mm}$ for the height. The analysis of the reliability of computation results will be helpful in estimating the accuracy of surveys and the correct interpretation of mining impacts.

In practice, deficiencies in observations from any reference network for some of its stations may prove to be problematic for surveyors. Then, it may be helpful to tie the current survey to the reference stations of another network. In the case of an unfavourable location of investment in relation to the reference stations utilised to tie the network, the lack of observations from a given station may result in the need to link the points to a reference station distant from them by approximately $100 \mathrm{~km}$. Such long vectors require longer static sessions. In most cases, the contractor will not be so cautious as to even consider such an unexpected situation from happening, which may cause problems with obtaining the results of post-processing of static satellite observations which would be of a sufficient quality.

In the light of the obtained surveying results, the reference stations of the ASG-EUPOS network can not be classified as higher-order than the commercial network stations. Classifying the reference stations of this CORS network as the first-order points, and the commercial network reference stations as the second-order points, does not seem to be justified from a practical point of view. The mere fact that the commercial CORS networks have been tied to the national system does not give reasons for such a diversification between the reference stations of the national network and of the commercial networks, although this is traditionally adopted in geodesy. Such a classification approach was developed back in times when satellite surveys did not exist. In addition, the analysed results have proven that better precision can be obtained using commercial networks than from the national network. 


\section{References}

1. Ustawa z dnia 9 czerwca 2011 r. Prawo geologiczne i górnicze (Dz.U. 2011 nr 163 poz. 981 z późn. zmian.)

2. Rozporządzenie Ministra Środowiska z dnia 28 października 2015 r. w sprawie dokumentacji mierniczo-geologicznej (Dz.U. 2015 poz. 1941)

3. Rozporządzenie Rady Ministrów z dn. 15.10.2012 r. w sprawie państwowego systemu odniesień przestrzennych (Dz. U. 2012 poz. 1247)

4. Rozporządzenie Ministra Administracji i Cyfryzacji z dn. 14.02.2012 r. w sprawie osnów geodezyjnych, grawimetrycznych i magnetycznych (Dz. U. 2012 poz. 352)

5. Rozporządzenie Ministra Spraw Wewnętrznych i Administracji z dn. 9 listopada $2011 \mathrm{r}$. w sprawie standardów technicznych wykonywania geodezyjnych pomiarów sytuacyjnych i wysokościowych oraz opracowywania i przekazywania wyników tych pomiarów do państwowego zasobu geodezyjnego i kartograficznego (Dz.U. nr 263, poz. 1572)

6. Uznański A.: Kolejowa osnowa geodezyjna - przepisy oraz praktyka pomiarowa. Drogi Kolejowe. Zeszyty Naukowo-Techniczne Stowarzyszenia Inżynierów i Techników Komunikacji RP. Oddział w Krakowie. Nr 2 (101), Kraków, (2013)

7. Dong D, Bock Y.: GPS network analysis with phase ambiguity resolution applied to crustal deformation studies in California. Journal of Geophysical Research, 94 (1989)

8. Ashkenazi V., Roberts G.W., Experimental monitoring of the Humber bridge using GPS, Proceedings, Institution of Civil Engineers, Vol. 120, (1997)

9. Chrzanowski, A., Szostak-Chrzanowski A.: Deformation monitoring surveys - old problems and new solutions. Reports on Geodesy vol. .2/87, (2009)

10. Vermeer, M.: Review of the GPS deformation monitoring studies commissioned by Posiva Oyon the Olkiluoto, Kivetty and Romuvaara sites, 1994-2000. STUK-YTO-TR, 186. Helsinki, (2002)

11. Spreckels V., Schlienkamp A., Schulz M., Drobniewski M., Bechert S., Schäfer F.: Aufbau einer GNSS Referenzstations-Infrastruktur für das GeoMonitoring von Bodenbewegungen. Conference: GeoMonitoring Tagung 2018, (2018)

12. Gili J.A., Corominas J., Rius J.: Using Global Positioning System techniques in landslide monitoring. Engineering Geology 55(3), (2000)

13. Eckl C., Snay R., Soler T., Cline M., L. Mader G.: Accuracy of GPS-derived relative positions as a function of interstation distance and observing-session duration. Journal of Geodesy. 75, (2001)

14. Firuzabadi D., King RW.: GPS precision as a function of session duration and reference frame using multi-point software. GPS Solutions, 16(2), (2011)

15. Baarda W.: Statistical concepts in geodesy. Publication on Geodesy, New Series, Netherlands Geodetic Commision, vol. 2, No 4, Delft, (1967)

16. Baarda W.: A testing procedure for use in geodetic networks. Publication on Geodesy, New Series, Netherlands Geodetic Commision, vol. 2, No 5, Delft, (1968)

17. Uznański A.: Praktyka realizacji $i$ opracowania pomiarów satelitarnych punktów kolejowej osnowy geodezyjnej. Zeszyty Naukowo-Techniczne Stowarzyszenia Inżynierów i Techników Komunikacji RP. Oddział w Krakowie, Nr 2 (104), Kraków, (2014) 